\title{
Losing Sight of Atmospheric Sounds in Televised Nature Documentary
}

\begin{abstract}
The production of soundtracks for televised nature documentaries involves complexities in balancing the audience's sonic perceptions and emotions with audio content and scientific rigour. In addition, soundtracks need to be congruent with audience expectations and commercial imperatives. Popular televised nature documentaries often appear to be narrative melodramas with environmental soundscapes submerged by narration and music. This paper examines the correlations between perceptual agency, educational practices and production constraints with regards to sound production in nature documentaries. The purpose is a clarification surrounding the causative factors and results of the curious neglect for the sound of our natural world within an industry dedicated to the sensory portrayal of nature.
\end{abstract}

\section{PERCEPTUAL MEDIATION}

We have lived on two different planets for decades: one threatened by ecological collapse, the other characterised by televised wildlife programmes (Monbiot 2002). Whether in cinematic contexts or in the

\section{KEYWORDS}

atmospheres audio technology broadcast documentary mixing music nature perceptions recording television 
everyday, the perceptual and interpretative parameters generated by sonic effects have repercussions on the audible environments transmitted by sound creators to their audiences. A rapidly evolving reliance on recorded visual 'truth' weakens the legitimacy of sound to exist both within and outside our lives; its substance is at once fleeting and exact when associated with the sounds of a world that exists without human interference. Nevertheless, humans are not separate from nature therefore it is possible to establish an 'ontological spectrum of naturalness' (Stephens 2000: 288-289, italics in text). In that instance, 'naturalness' reflects the extent to which a location and its associated environmental conditions and characteristic flora and fauna are unaffected by human activities. Audiovisual representations of these environmental sonic environments are examples of the ways a 'spectrum' of naturalness can be established. In that context, and because of the perceptible qualities of sonic information and the spatiality they generate, the word that humans understand as 'nature' could be replaced with the experience of 'life-world'. Philosopher Edmund Husserl formulated the concept of the 'life-world' (1970: 32); an experience that precedes and leads to consciousness. Dermot Moran describes the life-world as 'the world of pre-theoretical experience which is also that which allows us to interact with nature and to develop our own cultural forms' (2000: 181).

Although we might not be conscious of the ways our bodies interpret the full spectrum of the sonic world, we individually and collectively develop cultural awareness of audible systems of communication known as soundscapes. The information generated within these systems is constantly 'being interchanged between individuals of a community and their sonic environments' (Järviluoma 2009: 388). Our shared soundscapes are richer and vaster than our eyes would believe but our general expectations about sound reveal both our blindness and ways of listening. It is not surprising to some, but startling for others, to notice the global rise of anthrophony, a term used to generally describe the range of man-made sounds, and the gradual muting of some biophonic and geophonic sonic activities. Soundscape recordist and ecologist Bernie Krause has been capturing sound for more than 40 years, and half of his archives are now composed of sounds generated by extinct species (Krause 2002: 29).

Relationships between humans and other living species are now strained and fragile; mediatised representations could be the only ways for many people to have a learning experience about non-human exotic species (Jacobs and Stibbe 2006: 1). For nature and wildlife sound recordist Gordon Hempton, soundscape recording is different from wildlife and nature recording; he defines it as 'recording the human experience of listening (with healthy ears) to the place we are in' (2015). However, it is difficult to determine where the sounds of naturalness, and correlated visual appearance, start and finish, knowing that a lyrebird can chant the sounds of mechanical saws thus 'singing its own requiem' (Attenborough 2014). This 'real' oddity reflects the impact of sound in nature documentary for the simple reason that the authenticity of vision can be doubted if there is a lack of veracity in the accompanying soundtrack. 
The faithfulness of vision can also be questioned by the content of the accompanying soundtrack and the references to space that it unveils: as we see the lyrebird on screen, shouldn't the sounds of mechanical saws be at a distance and attenuated? The example of the lyrebird addresses the potential disconnection between mediated representation of sonic nature and the authenticity of sonic events as they happen: the truthfulness of the natural sonic source has to be validated visually to be believed.

\section{MEDIATING NATURE}

Modern media has objectified the world and disembodied us through the filtering of vibrational perceptions. Daniel Deshays notes that the problem of sound is its 'invisibility' (2010: 48). This invisibility occurs when sound is so well integrated into a movie that it is inconspicuous, yet it has the ability to influence our physical experience of the film. Sounds coming from our environment are sometimes foreign to our eyes, which are trained for speedy absorption and fast recognition of visual information. Susan Sontag emphasises our inconsistent lack of trust in the sonic world that we inhabit, regardless of the nature of its 'content': 'Photographs furnish evidence. Something we hear about, but doubt, seems proven, when we are shown a photograph of it' (1977: 5). On-screen sound provides perceptual elements leading to an audio-vision (Chion 2016: 150, italics in text) that gives the image our full conscious attention while feeding our other senses without mindful acknowledgement. A traditional cinematic convention requires that a good soundtrack goes unnoticed if 'done really well', remarks Natural History New Zealand (NHNZ) post-production manager Tom Koykka (2016b). Sound doesn't disturb the eye but comforts it in its 'objectivity'.

In the case of sound for modern nature programmes, thematic and formal realisms tend to merge seamlessly. 'Wildlife and nature documentary' has become a consensual term for television programmes that provide educational content in entertaining ways and that appeal to a variety of audiences. Their storylines require very specific sonic material reflecting the behaviours of animals but also their appearance within the frame; traditionally, a close-up might narrow the range of audio information relayed to the spectator. Most of the time the process of deconstruction and re-assembly inherent to their making is more a testament to human cultural reliance on visual input rather than to perceptions of sonic ubiquity and atmospheric environments. An important consideration is whether it is the capture of sound or its subsequent treatments that impact on communal expectations of what nature in televised documentary 'should sound like' in order to 'look real'.

Audiovisual documentary genres have been in constant flux, although their basic operative mode remains to present facts and develop arguments convincingly while reshaping audio and visual recorded components. Bill Nichols refers to the presentation of facts relayed by choices of audiovisual material as a 'voice', 'a moiré-like pattern formed by the unique interaction of all a film's codes', applicable to all modes of documentary (1983: 18). Concepts of documentary may embody different 
modes of recording, exposing and legitimating factuality: participatory, expository, observational, reflexive, poetic and others. Regardless of the different genres or academically formulated modes of filmmaking, documentaries present authored perspectives to expectant audiences, their perceptual systems and their innate sense of knowing the world 'through the body'. However, Maurice Merleau-Ponty's conception of our body being our 'means of communication with the world' (2008: 106) seems almost incongruous when exposed to the construction of hyper-mediated, and sonically enhanced, moving images of wildlife.

Regardless of the seemingly inconspicuous role of environmental sound, its recording has become a determining factor in expressing aspects of nature and establishing the listened and the felt, the proximal and the far, the absorbed and the unheard. The transformation, from a phenomenological absorption of sonic signals to a listening to sounds as meaningful (Ihde 2007: 4, italics in text) was revolutionised by recording technologies facilitating perceptual valorisation. Schizophonia exposes the fact that electroacoustic recordings allow for 'the splitting of sounds from their original contexts' (Schafer 1994: 88). Johnathan Sterne emphasises this phenomenological progression of modes of listening by stating that the ear is now part of 'a whole field of hearing equipment' (2015: 69, italics in text). Sometimes, the immediate re-listening to a recording brings to the surface the presence of sounds unheard at the time (Deshays 2010: 86). Listening a posteriori to recorded vibrations can produce surprise: the absence of a sound felt, perceived and learned, can be as confusing as the presence of felt but unheard sound captured at the time of recording, regardless of the mode of production employed.

As in fiction filmmaking, documentary makers develop modes of representation that are often tributary to technical elements of production and their ensuing embodied practices. German filmmaker, Alexander Kluge, outlines the nature of documentaries as such:

A documentary film is shot with three cameras: 1) the camera in the technical sense; 2) the filmmaker's mind; and 3) the generic patterns of the documentary film, which are founded on the expectations of the audience that patronizes it (cited in Minh-Ha 1990: 88).

As well as by addition, the camera also discriminates and denies by abstraction, and so does sound creation in all its forms. David Attenborough succinctly describes the 'three cameras' used for treatment of sound and images in nature history documentary:

You distort speed if you want to show things like plants growing, or look in detail at the way an animal moves. You distort light levels. You distort distribution, in the sense that you see dozens of different species in a jungle within a few minutes, so that the places seem to be teeming with life. You distort size by using close-up lenses. And you can equally well distort sound (Burgess and Unwin 1984: 103). 
Audio and visual technologies have revolutionised televised representations of nature to offer more intimate relationships with animals, land and seascapes. Representations of natural life have evolved due in part to the miniaturisation of recording technologies, colour TV broadcasting, and an increase in collaboration between scientists, naturalists and broadcasters. Microscopes, computer-generated imagery (CGI), as well as infrared, ultra-slow and ultra-high-speed cameras, and ultrasound microphones give technology the power to track its animal 'prey' (Bagust 2008: 223). Audio-recording technology didn't evolve as rapidly as its visual counterpart, and slowed between the 1929 stock market crash and the end of World War Two (Pourshariati 2012: 23). In 2014, wildlife sound recordist Chris Watson remarked that he still records using technology that was used by Attenborough himself in the 1950s, a directional microphone with parabolic refractor allowing him to capture precise sounds at a distance emitted from sources often unseen (Attenborough 2014).

The first synchronised sound wildlife documentary, Matto Grosso: The Great Brazilian Wilderness (Crosby 1931), was initiated by Fenimore Johnson, son of the Victor Talking Machine founder E.R. Johnson. He embarked on this expedition wanting to record a disappearing indigenous culture, and 'to be the first expedition to bring back actual sound recording films taken in the jungle' (Pourshariati). Although this audiovisual adventure was not scripted in advance, Johnson was supported by a Hollywood crew. The technical team was led by Floyd Crosby who won an Oscar for cinematography on the docufiction, Tabu: A Story of the South Seas (Murnau 1931); he was more experienced than other team members in building a narrative. For the expedition in the Matto Grosso, Crosby used an experimental camera weighting 70 pounds with a mounted sound head. With all but one microphone surviving the humidity, and although they used standard $35 \mathrm{~mm}$ film, their technical set-up seemed to pre-empt production techniques that 'a video/ news crew works with today' (Pourshariati 2012: 21-22). The well-funded expedition also comprised a professional ethnographer, an artist, and a zoologist.

Johnson wanted to record the 'disappearing'. His wish denoted a prescience of our current relationships with the life of the wild and the reciprocal relationship between audiences' behaviour and commercial pursuits. The outcomes of his ethnographic expedition and its adventure overtones provided different interpretive meanings, but in the latest incarnation of its edit (in 1941) almost all of the recorded synch sound was removed 'as if to imply that it is preferred that the omniscient narrator take control' (Pourshariati). Thus, rather than 'bringing back sounds from the jungle' this final edit, entitled Primitive Peoples of Matto Grosso: Xingu (Nemeth 1941), submerges the recorded atmospheric soundscape with music and authoritative voice-over narration. The fate of 'modern' musical versions of sound-making for nature documentaries aimed at general audiences seemed then to be sealed. The musical part of a nature documentary 
soundtrack can shape both visual and narrative representations of nonhuman species.

\section{ENTERTAINING THE SENSES}

Non-human species have no choice as to how they are represented sonically and how their lives will be subsequently valued. Sound can influence the ways 'fictional truth' is conveyed to millions of viewers worldwide. In that context, we cannot dismiss the importance of audio-visiogenic effects, as sounds can reinforce what the visual information would 'already say by itself' (Chion 2016: 153, italics in text). It is beyond the scope of this article to comment on musical aesthetics but it is within its parameters to notice the sensory effects provoked by elements of soundtracks. The fiction film Jaws (Spielberg 1975), is a testament to our fear and attraction to the power of nature. In Jaws, the assignment of an ominous musical motif to its presence gave a shark a personality although its full body was kept invisible for the first 81 minutes of the film (Kermode 2015). Whether in fiction or in many documentaries, sharks quickly became eating machines devoid of personality with musical gestures as sinister companions. Despite their 'fictive' status, these audio and visual portrayals implied the unpredictability of sharks' behaviour and provided a 'dominant sense of reality' (Papson 1992: 68) thus also keeping documentary audiences on edge. It is undeniable that musical scores generate dramatic pace but televised documentaries should also reflect the fact that lives in the wild 'are not ordinarily accompanied by music' (Rogers 2015: 7). In the case of such audio nature documentaries, we could substitute a vococentrism attracting human auditory attention (Chion 2016: 156) to a subtle sonorocentrism, an attraction to the voice of our shared soundscape and its ubiquitous anthrophony.

Watching a televised nature documentary can be a strenuous listening experience when a specific component of the soundtrack overpowers all other sonic elements. Yet, the near continual musical presence over, or integrated with, animal and landscape audible elements has become normalised within the genre. In 1995, for example, the soundtrack of the episode entitled Surviving, that was part of the BBC series The Private Life of Plants (Nightingale 1995), seemed to contain less music than a later programme on the same subject, Plants (Lucas 2009), in the BBC series Life. The inimitable voice of David Attenborough leads both programmes but there are major divergences in their soundtrack compositions. The 1995 programme is 49 minutes long; its soundtrack leaves room for atmospheric sounds to breathe, animal calls to be heard and location talk and narrative voice-over to be clearly understood. Fast track to 2009 on similar subjects in different locations but with the same writer/presenter. The 53 minute episode Plants is devoid of musical scores for only eight minutes, and the music composed by George Fenton is more robust; music underlays commentary most of the time.

Forward to 2012 and to a new BBC series, How to Grow a Planet, with an episode written, directed and produced by Nigel Walk (2012), and entitled The Power of Flowers. Its running time is 50 minutes: music is 
present wall-to-wall except for seven and half minutes of filmed interviews with scientists. Walk is never in shot, yet at times his voice-over is almost unintelligible, so thoroughly is it submerged by music, giving the impression that he is trying to talk over the music. The BBC acted by lowering the volume of the musical content in some of its documentaries after public complaints of the unintelligibility of vocal commentary due to excessive music levels (Cohen 2011).

There has been a gradual change in the ways soundtracks for nature documentaries are now dominated by music at the expense of sounds of wild nature. Tom Koykka also became aware that the education component of documentaries in the U.S.A has diminished to the benefit of entertainment, and music is able to increase this 'fluffiness' factor (2016b). Concurrently, NHNZ sound mixer, Errol Samuelson, remarks that the European market seems to require less 'sporadic musical presence' in contrast to the American market that privileges wall-to-wall music (2016). While co-working and editing Le Monde du Silence (Cousteau and Malle 1956) with Jean-Jacques Cousteau, Louis Malle disapproved of Cousteau's show business approach to the documentary with the addition of music, reportedly saying, 'It is not what it should be, it is becoming like Walt Disney' (Cooke 2015: 114).

On the one hand, the emotional impact of the music score can reinforce a visual action's kinetic rhythm. Stacey Hertnon, sound mixer at NHNZ, remarks that 'if it's a frantic, fast paced thing and if you did it with sound effects, you wouldn't get that feeling, it depends' (2016). Music might also provide adequate background for a very slow visual capture, for example. On the other hand, a participant to a British study on the reception of wildlife televised documentaries lamented the lack of sensory information offered and ways to express:

... thoughts and feeling and sensory information about how the rain feels on their face and their feet are covered in blisters, not to mention mosquito bites etc. Not someone determined to teach me something ... I never feel that documentaries give me the impression of being there. Too much sensory information is missing (Austin 2007: 149).

Obviously, not all nature documentaries rely on musical score to communicate the rhythm of animal life: such an approach is often linked to technologies, budget and the intentions of the documentary makers. Similarly, 'the voice of God' mode is not always beneficial to good viewing and neither is poor sound quality. Of course, generalisation can be easy; the production of the authored televised nature documentary is extremely complex and is mostly led by visual representations rather than bodily sensations evoked by auditory stimuli. But television audiences ought to be offered ways to feel the immediacy of sonic vibrations surrounding the objects of vision. The soundtrack of Leviathan (Castaing-Taylor and Paravel 2012), an experimental ethnographic documentary shot on a commercial fishing boat, gives to the viscerality of sound 'a constitutive 
role in exploring the assemblage of human, animal, and machinic existence' (Kara and Thain 2015: 187). Admittedly, Leviathan is not a 'nature documentary' and was made by academics for research purposes. Nevertheless, it had success in film festivals by virtue of the phenomenological experience provided by the 'life-world' qualities of its soundtrack. Could popular televised nature documentaries offer similar ways to perceive the world?

\section{CAPTURE}

Whether captured within animal and plant habitats or digitally created, sounds and images of the exotic become 'virtual ecosystems' by way of their propagation and viewing (Bagust 2008: 213). The layering of these audio narrative elements aims to elicit knowledge and emotions while representing the world in a manner that would sustain scientific scrutiny and fit anthropomorphic values. From that perspective specific elements of documentary sound can be an important factor in the categorisation of programmes. For example, Derek Bousé suggests that voice-over narration should remain 'a constant, if not a necessity' in the production of nature documentaries (1998: 121). At the core, could representation of wild nature without music include the soundscape in its totality, without a documentary being labelled as observational, or its form being decried for not feeding verbal information to audiences, or for not fitting current popular entertainment values? Kestrel's Eye (Kristersson 1998) followed the lives of a family of kestrels living in a Swedish church steeple. Filmed over two and half years, the 89-minute documentary is devoid of music and voice-over. It privileges instead the atmosphere captured on location thus bringing to the fore the reactions of the birds to the sonic events occurring in their natural habitat - ones we share with them. This approach lets their sensory world lead our knowledge to grow 'by sounds', as we can hear the rumble of airplanes, a car door alarm, the relentless sweeping of snow in the cemetery. Audiences are mostly alerted to the kestrels' reactions when the birds' heads turn towards the causal sources of high pitched sound (the low rumbles of distant airplanes don't seem to grab the kestrels' attention). Director/cameraman/sound recordist, Mikael Kristersson, had hidden an audio tape-recorder with a microphone in the nest cavity, therefore 'discovering' sound and the birds' vocalisation a posteriori. These different techniques contributed to a raw observational documentary that brought 'the actual texture of history in the making' (Nichols 1983: 20) by exposing the mediated but intrinsic phenomenological relationships between subjects, makers and audiences all exposed to the same soundscape.

Atmospheres are usually classified as sound effects and their audible presence is not always best represented. Radio programmes celebrating wildlife, however, provide an exception to this practice. For example, the annual 'Dawn Chorus Day' on BBC radio. Approaches to transmitting perceptions of similar events on radio can be radically different, with some presenters privileging verbal, anthropomorphic description over animal calls during live broadcast (Blunt 2015) and others letting biophonic and 
geophonic sounds trigger audience senses in post-produced programmes (Dawes 2013). Regardless of their treatments, these audio-mediated experiences encourage listeners to imagine the scene visually. This process welds individual and collective practices of perceptual agency, understood as 'the conscious focusing of sensory attention that can yield differing experiences of the same event' (Monson 2008) and re-aligns human symbiotic cultural exchanges with sounds of the perceived world.

Location sounds for television began to generate interest from the 1950s; writer/presenter David Attenborough started recording visual material and unsynchronised magnetic sound in exotic locations for natural history programmes instead of relying on artificial reproduction (Park 2014). The sensitivity of microphones has increased but the immediacy of a recording often depends on the distance between the microphone and the object of audible interest. Digital and wireless technology provide other ways to reposition the mediating body within sonic fields. Most professionals mention the necessity to bridge the physical gap between subjects and instruments for audiovisual capture by being as close as possible to the selected sound emitter, so as to avoid the natural background soundscape. To record a Madagascar hissing cockroach, Chris Watson recalls placing his microphone 'about two or three millimetres from the animals back' but adds that this recording was performed in an apartment in noisy Greenwich Village (2015). Nature sound recordist Gordon Hempton also aims for selective recordings but refers to wildlife recording as 'a generic term that describes recording native animal species in their native environment (either selectively or ambient)' (2015).

Both Hempton and Watson mention music when talking about their recording practices. Watson declares that his aim is 'to achieve recordings that I could suggest we use instead of music' (2015: my italics) while Hempton states that he 'feels the music in most natural places and seldom in built environments, but this can occur in both' (2015: my italics). Chris Watson speaks of atmosphere tracks with a small dynamic range, of single points of sound captured in mono and of sounds of habitats that cover a wide dynamic range (Musitech.net 2013). Sound recordists use their bodies differently when recording 'passively', immobile and in waiting, or when recording 'actively', for example, by scratching tree bark. In any case their sensory knowledge is constructed there and then, involving all perceptual modalities: vision, sound, touch, taste and smell. The physical distance between sound equipment, a recordist's body and animals in visual focus can also be compelled by anthropomorphically contextualised representations that talk about human characteristics rather than the life of the wild:

You might have a close-up shot of an owl ripping apart the body of its prey but could not have got the sounds it was making because you couldn't get a gun-mike near enough. So you then manufacture the sound in the studio. That seems to me to be justifiable as well. Sometimes it may even be distracting to put in the actual sounds. If we put in all the cicada calls in the jungle with which people are 
quite unfamiliar, and your subject is something other than cicadas, then that might well distract people's attention from the subject at issue. And we might have to explain that the curious noise that sounds every half-minute or so is not a man hitting an anvil with a sledge-hammer but a bell-bird (David Attenborough cited in Burgess and Unwin 1984: 103-104).

In this context, some 'voices' of nature have to be suppressed; soundtracks aiming to reflect the reality of habitats often mute the rawness of the existing soundscape better to fit into an audience's innate 'knowledgeable fantasy' of visual wild nature.

\section{DISAFFECTION?}

The re-launch of the BBC television service after World War Two allowed for natural history documentaries to introduce a new vision of wildlife' (Davies 1998: 102). In 1955, using mainly mute films of good quality produced by amateur naturalist filmmakers, the Natural History Unit of the BBC (NHU Bristol) began to televise a regular studio-based series, Look, described as 'televised naturalist's lecture with excerpts of film' (Richards 2013: 145). Public interest was then transformed by a BBC television broadcast of a short German documentary entitled Woodpeckers (Sielmann 1954), that showed the intimate life of woodpeckers made by shooting through the back of their nesting hole. Over the past 60 years the technical and commercial developments intrinsic to the unveiling of nature have been relentless.

During the last decade the 'nature and wildlife' documentary genre has been through major corporate shifts linked to proliferation of specialised nature channels and other modes of diffusion. In order to survive, production companies have had to merge and/or diversify. Production costs for television have increased and the budget on which a project was sold will rarely match the mounting costs occurring between its pre-sale and first broadcast. Phil Fairclough, formerly of the BBC Natural History Unit, stated in 2001 that:

... we might occasionally use the Survival brand if we feel there's some mileage in it for us, but by calling ourselves Granada Wild we're telling potential clients that we're a hybrid producer, encompassing travel and adventure as well as natural history, backed by an internationally known brand. (Clarke 2001).

Producers of documentaries may constrain costs by employing directors and cameramen to shoot footage and record sound themselves: recording sound in the field is neglected and sound quality has become an afterthought. Sound recordist Chris Watson spent 14 years recording on location to provide sounds for different series of celebrated BBC blue chip nature documentaries led and narrated by David Attenborough. The label 'blue chip documentary' is a sub-genre defined as such because of the absence of human presence on screen and the substantial budgets 
that allow for sound recording on location. However, merging and diversification have been felt across the industry and in-house field trips for the purpose of recording specific environments and animal behaviour have become a practice of the past, to the effect that now some broadcast programmes have 'no actual animal calls, there's only the Foley, the music and an atmos track (without anthrophonic trace)' (Samuelson 2016). However, music is 'the big item' that has to be licensed and budgeted for every project (Koykka 2016b). By contrast to lucrative visual footage and music, animal and environmental sounds have no tangible commercial value although, ironically, extinctions of wildlife might one-day drive the prices up (Koykka 2016b).

An increased number of nature documentary productions have followed the trend of low cost host-driven reality TV and its fast production turn-around (Koykka 2016b). Sometimes oblivious to sound quality, directors and visual editors lock their choice of audio before sending the different audiovisual components to the audio post-production team: then, editorial changes are rarely possible (Koykka 2016b). Upon receiving this material, the post-production sound team carefully consider the technical requirements stated in the legal contract that binds them with production companies and broadcasters; the team then set up a template of audio technical criteria relevant to the product and its market. It is not uncommon, due to the proliferation of digital delivery platforms, legal obligations and specialised television networks, to have more than six different versions of a programme's sound mix and deliverables (Koykka 2016a).

A problematic element driving sound quality in the television industry is loudness. Loudness compliance severely reduces professional creative aspects of post-production for television as it limits dynamic range to fit a narrow band (Samuelson 2016). Broadcasters' sound mixing guides regulate loudness using defined metered standards such as the EBU R218 defined by the European Broadcasting Union, or the OP-59 in Australia (Electronic TC 2015). Thus a first mix could sound great and use a varied dynamic range 'but then you look at it on the meters and it's illegal' (Hertnon 2016). To exacerbate the situation, compliance also depends on the often poorly aware ears of producers and other individuals working for television networks. Producing becomes a frustrating experience as 'mixing-to-the-meter is an anathema to the mixers who were trained to use their ears' (Hillman and Pauletto 2016: 86). Mixers at NHNZ echo this state of affairs when reflecting on the reduced dynamic range available for television productions, and the surprise of colleagues working in fiction film about these restrictive parameters (Hertnon 2016, Samuelson 2016). The gap is wide between the realities of television broadcasting, the ears of the listeners, the knowledge and budget of producers and the upcoming generations of 'visio-listeners' often unaware of their own perceptual capabilities and the richness of their environments.

A primary concern of sound post-production for nature documentary is to have the right sounds for the animals and for their calls to correspond to their habitats, and to discard anthrophonic 'noises' that might distract 
from the vocal commentary (Hertnon 2016). Similarly, culling the full scope of soundscapes and using sounds to only highlight parts of moving images does not allow for an exploration of the human perceptual system which mediates our experience of the world. Awareness of our rich sonic atmosphere clashes with a hunger to represent, and sonically simplify, natural life on this planet. In that context, it is not surprising that soundtracks of some nature documentaries, made over a year of study by academic students in science communication, for example, with an attention to location recording, can creatively mix extensive bio-geophonic content and minimal musical input to move and educate audiences at the same time (Science Communication 2016). Sensory 'reality' hits when students, often unaware of sales constraints, reach the production line where 'we don't make the shows for ourselves, we make it for our clients' (Hertnon 2016). With a week to produce a one-hour programme there is no time for audio exploration to enhance the script. In fact, the work currently performed revolves around a script laid out to use vocal narration 'as its base, place it around the sound effects and match the pictures' (Samuelson 2016).

Anthrophonic sonic activities on a televised nature documentary soundtrack are silenced by default in order to avoid visual distractions. Sound professionals train their ears and bodies to record as little anthrophonic data as possible and thus perfectly to isolate sound events. In this context audio technologies have restricted human listening by limiting the spectrum of sonic naturalness to just what could be visually relevant at the editing stage. Mixing 'in the box' on a personal digital audio workstation (DAW) can also contribute to a poor understanding of the importance of the atmospheric soundscape. The vast choice of hardware, software and plug-ins available might increase a spirit of experimentation in sound manipulation, but this approach can result in an over-processing of sounds to the detriment of good quality original recordings. According to sound mixer Michael Minkler, the use of a DAW privileges convenience over quality: manipulated soundtracks can then become too 'digital sounding' (cited in Kassab 2010: 16). Although young directors often think that 'in post-production you can remake a soundtrack entirely' (Hertnon 2016), there is no substitution for feeling, listening and recording sound in the human life-world. In this light, we should suggest to media students, prior to their creative specialisation, to focus first on location recording to feel, listen to and 'watch' the invisibility of sounds before concentrating on schizophonic listening and visual post-production practice.

\section{CONCLUSION}

The production and viewing of televised nature documentaries unveil the extreme complexities of simultaneously informing and entertaining a vast range of audiences. The nature wildlife documentary genre is a thriving industry worldwide; yet production and post-production companies have been subject to various operational changes, evolving technologies, ever-shrinking budgets and the progressive disappearance of 
professional in-house training. Tom Koykka is cautiously optimistic: 'So again the cycle will continue where reality TV will lose favour and documentary will come up and eventually maybe it will revert back to real' (2016b). In the present world of televised nature documentary, the 'real' is extremely theoretical. It currently depends on focus groups as well as on the personal tastes of those in charge of production and diffusion.

In the context of popular televised documentary, an overload of music could 'dumben and numben' the ears of the public (Watson 2015). A consideration is whether the nature documentary without music would be accepted into the mainstream nature television channels, or be restricted to film festivals. On this topic, Watson points at a public surge in wanting to absorb mediated nature by other means than fast paced, musically deafening and over-commentated television programmes. This suggests that televised nature documentaries with limited or absent musical accompaniment may be readily accepted. Moreover, 'slow documentaries' bring another viewing experience to the mediated sounds of televised nature as the interlacing of shots and atmospheric off-screen sounds add a layer of knowledge intrinsic to each viewer's innate sense of knowing. In conclusion, a tighter connection between the practices and theories of listening and sound making for nature documentaries could result in the perceptual acceptance of 'imperfect' sonic nature. It is not so far-fetched to ponder whether sound production, and the ensuing composition of soundtracks, could one day re-define modes of documentary representation, within nature and wildlife genres in particular. Promoting an 'atmospheric nature documentary without music', or a 'musical nature drama', or a 'non-narrated atmospheric nature programme', might also inform audiences on the multiple ways sound production influences sensations and audio-visual acquisition of knowledge.

\section{SOURCES}

Attenborough, David (2014), interviewed by Chris Watson, 19 January 2014, BBC Radio 4.

Austin, Thomas (2007), Watching the World: Screen Documentary and Audiences, Manchester: Manchester University Press.

Bagust, Phil (2008), “'Screen Natures”: Special effects and edutainment in "new" hybrid wildlife documentary', Continuum, 22(2), 213-226.

Blunt, Sarah (2015), 'Soundstage - Dawn Chorus', Best of Natural Radio, radio/ podcast, BBC Radio 4, http://www.bbc.co.uk/programmes/ p02nrv7r/episodes/downloads, accessed 10 May 2016.

Bousé, Derek (1998), 'Are Wildlife Films Really "Nature Documentaries"?', Critical Studies in Mass Communication, 15(2), 116-140.

Burgess, Jacquelin and David Unwin (1984), 'Exploring the Living Planet with David Attenborough', Journal of Geography in Higher Education, 8(2), 93-113.

Castaing-Taylor, Lucien and Verena Paravel (2012), Leviathan, film, U.S.A: The Cinema Guild. 
Chion, Michel (2000), 'Audio-Vision and Sound' in Kruth, P. and H. Stobart (eds.), Sound, Cambridge: Cambridge University Press, 201-221.

Chion, Michel (2016), Sound: An Acoulogical Treatise, translated by James A. Steintrager, Durham, NC: Duke University Press.

Clarke, Steve (2001), Wild Kingdom...? http://realscreen.com/2001/08/ 01/uktrends-20010801/, accessed 10 September 2015.

Cohen, Danny (2011), 'Is the Background Music Too Loud?', BBC TV blog, 11 August 2016: http://www.bbc.co.uk/blogs/tv/2011/03/isthe-background-music-too-loud.shtml, accessed 11 August 2016.

Cooke, Mervyn (2015), 'Water Music, Scoring the Silent World' in Holly Rogers (ed.), Music and Sound in Documentary Film, London and New York: Routledge, 110-126.

Cousteau, Jean-Yves and Louis Malle (1956), The Silent World/Le monde du silence, film, France: FSJYC Production, et al.

Crosby, Floyd (1931), 'Matto Grosso the Great Brazilian Wilderness', Mato Grosso Expedition Collection, http://www.penn.museum/sites/ mattogrosso, accessed 15 September 2016.

Davies, Gail (1998), Networks of Nature: Stories of Natural History Film-Making from the $B B C$, unpublished thesis (PhD), University College London.

Dawes, Andrew (2013), 'Dawn Chorus Day', The Living World, radio/ podcast, BBC Radio 4, 5 May 2013, http://www.bbc.co.uk/ programmes/b01s7vtp, accessed 10 May 2016.

Deshays, Daniel (2010), Entendre Le Son, Paris: Klincksieck.

Electronic TC (2015), Broadcast Standards, http://www.tcelectronic.com/ loudness/broadcast-standards/, accessed 16 July 2016.

Hempton, Gordon (2015), personal communication, 11 November 2015.

Hertnon, Stacey (2016), interviewed by Isabelle Delmotte, 14 June 2016.

Hillman, Neil and Sandra Pauletto (2016), 'Audio Imagineering: Utilising the Four Sound Areas Framework for Emotive Sound Design within Contemporary Audio Post-Production', The New Soundtrack, 6(1), 77-107.

Husserl, Edmund (1970), The Crisis of European Sciences and Transcendental Phenomenology, an Introduction to Phenomenological Philosophy, translated by David Carr, Evanston: Northwestern University Press.

Ihde, Don (2007), Listening and Voice: Phenomenologies of Sound, 2nd ed., Albany: State University of New York Press.

Jacobs, George and Arran Stibbe (2006), 'Guest Editors Introduction: Animals and Language', Society E̋ Animals, 14(1), 1-7.

Järviluoma, Helmi, Meri Kytö, Barry Truax, Heikki Uimonen and Noora Vikman (2009), 'Conclusion' in Helmi Järviluoma, Meri Kytö, Barry Truax, Heikki Uimonen and Noora Vikman (eds.), Acoustic Environments in Change E Five Village Soundscapes, Tampere, Finland: TAMK University of Applied Sciences with University of Joensuu, Cultural Research. 
Kara, Selmin and Alanna Thain (2015), 'Sonic Ethnographies, Leviathan and New Materialisms in Documentary' in Holly Rogers (ed.), Music, Sound, and the Nonfiction Aesthetic, London: Routledge, 186-198.

Kassab, John (2010), An Investigation into the Creative, Technical and Workflow Innovations in Post-Production Film Sound in London, New York, San Francisco, Los Angeles and Wellington, Canberra: The Winston Churchill Memorial Trust of Australia.

Kermode, Mark (2015), “Jaws, 40 Years On: 'One of the Truly Great and Lasting Classics of American Cinema" ', The Guardian, 31 May 2015, https://www.theguardian.com/film/2015/may/31/jaws-40-yearson-truly-great-lasting-classics-of-america-cinema, accessed 24 August 2016.

Koykka, Tom (2016a), personal communication, 10 August 2016.

Koykka, Tom (2016b), interviewed by Isabelle Delmotte, 14 June 2016.

Krause, Bernie L. (2002), 'The Loss of Natural Soundscapes', Earth Island Journal, (Spring), 27-29.

Kristersson, Mikael (1998), Kestrel's Eye, film, Sweden: First-Run Features.

Lucas, Neil (2009), 'Plants', episode of Life, television series, UK: BBC.

Merleau-Ponty, Maurice (2008), Phenomenology of Perception, translated by Colin Smith, Oxon: Routledge.

Minh-Ha, Trinh T. (1990), 'Documentary Is/Not a Name', October, 52 (Spring), 76-98.

Monbiot, George (2002), 'Planet of the Fakes', The Guardian, 17 December 2002, https://www.theguardian.com/media/2002/dec/ 17/broadcasting.comment, accessed 10 August 2016.

Monson, Ingrid (2008), 'Hearing, Seeing, and Perceptual Agency', Critical Inquiry, 34(2), 36-58.

Moran, Dermot (2000), Introduction to Phenomenology, London: Routledge.

Murnau, Friedrich Wilhelm (1931), Tabu: A Story of the South Seas, film, U.S.A: Paramount Pictures.

Musitech.net (2013), Recording the Natural World Tutorial, Tutorials, http://www.musictech.net/2013/02/recording-the-natural-world/, accessed 20 August 2015.

Nemeth, Ted (1941), Primitive Peoples of Matto Grosso: Xingu, The Mato Grosso Expedition Collection, https://archive.org/details/ upenn-f16-4013_1941_Primitive_Peoples_of_Matto_Grosso, accessed 10 September 2016.

Nichols, Bill (1983), 'The Voice of Documentary', Film Quarterly, 36(3), 7-30.

Nightingale, Neil (1995), Surviving, television series, UK: BBC.

Papson, Stephen (1992), "Cross the Fin Line of Terror": Shark Week on the Discovery Channel', Journal of American Culture, 15(4), 67-81.

Park, William (2014), 'The Hidden Art of Sound Design, Part Two', Refractive index: https://refractiveindex.wordpress.com/2014/02/20/ the-hidden-art-of-sound-design-part-two/, accessed 20 June 2016. 
Pourshariati, Kate (n.d.), A History of an Expedition to Mato Grosso Brazil and Matto Grosso, the Great Brazilian Wilderness (1931), http:// www.penn.museum/sites/mattogrosso/, accessed 10 January 2016.

Pourshariati, Kate R. (2012), 'Expedition to the Amazon, the First Documentary Film with Sound', Expedition, 55(2), 18-25.

Richards, Morgan (2013), 'Global Nature, Global Brand: BBC Earth and David Attenborough's Landmark Wildlife Series', Media International Australia, (146), 143-154.

Rogers, Holly (2015), 'Music, Sound, and the Nonfiction Aesthetic' in Holly Rogers (ed.), Music and Sound in Documentary Film, London \& New York: Routledge, 1-19.

Samuelson, Errol (2016), interviewed by Isabelle Delmotte, 14 June 2016. Schafer, R. Murray (1994), The Soundscape: Our Sonic Environment and the Tuning of the World, 2nd ed., Rochester, Vermont: Destiny Books.

Science Communication, Otago University (2016), Wild Nature Mini Film Festival, Dunedin, NZ: Otago Museum.

Sielmann, Heinz (1954), Woodpeckers, film, West Germany: Institut für Film und Bild in Wissenschaft und Unterricht (FWU).

Sontag, Susan (1977), On Photography, New York, London: Anchor Books Doubleday.

Spielberg, Steven (1975), Jaws, film, USA: United International Pictures. Stephens, Piers H.G (2000), 'Nature, Purity, Ontology', Environmental Values, 9(3), 267-294.

Sterne, J. (2015), 'Hearing' in David Novak \& Matt Sakakeeny (Eds.), Keywords in Sound, Durham \& London: Duke University Press, 65-77. Walk, Nigel (2012), The Power of Flowers, episode 2 of How to Grow a Plant, television series, UK: BBC, aired 14 February 2012.

Watson, Chris (2015), interviewed by Isabelle Delmotte, 11 November 2015.

\section{CONTRIBUTOR'S DETAILS}

Isabelle Delmotte is a Lecturer in Screen and Media Studies at the University of Waikato (New Zealand). As a multi-media practitioner her interests involve the role of creative practices as research tools and as vehicles for interdisciplinary collaborations. Past and current academic research projects have explored phenomenological aspects of professional sound-design practice for the screen, and their relationships to perceptual agency and acoustic ecologies.

Contact: isabelle.delmotte@waikato.ac.nz 


\section{Your short guide to the EUP Journals Blog http://euppublishingblog.com/}

A forum for discussions relating to Edinburgh University Press Journals

\section{The primary goal of the EUP Journals Blog}

To aid discovery of authors, articles, research, multimedia and reviews published in Journals, and as a consequence contribute to increasing traffic, usage and citations of journal content.

\section{Audience}

Blog posts are written for an educated, popular and academic audience within EUP Journals' publishing fields.

\section{Content criteria - your ideas for posts}

We prioritize posts that will feature highly in search rankings, that are shareable and that will drive readers to your article on the EUP site.

\section{Word count, style, and formatting}

- Flexible length, however typical posts range 70-600 words.

- Related images and media files are encouraged.

- No heavy restrictions to the style or format of the post, but it should best reflect the content and topic discussed.

\section{Linking policy}

- $\quad$ Links to external blogs and websites that are related to the author, subject matter and to EUP publishing fields are encouraged, e.g.to related blog posts

\section{Submit your post}

Submit to ruth.allison@eup.ed.ac.uk

If you'd like to be a regular contributor, then we can set you up as an author so you can create, edit, publish, and delete your own posts, as well as upload files and images.

\section{Republishing/repurposing}

Posts may be re-used and re-purposed on other websites and blogs, but a minimum 2 week waiting period is suggested, and an acknowledgement and link to the original post on the EUP blog is requested.

\section{Items to accompany post}

- A short biography (ideally 25 words or less, but up to 40 words)

- A photo/headshot image of the author(s) if possible.

- Any relevant, thematic images or accompanying media (podcasts, video, graphics and photographs), provided copyright and permission to republish has been obtained.

- Files should be high resolution and a maximum of $1 \mathrm{~GB}$

- Permitted file types: jpg, jpeg, png, gif, pdf, doc, ppt, odt, pptx, docx, pps, ppsx, xls, xlsx, key, mp3, m4a, wav, ogg, zip, ogv, mp4, m4v, mov, wmv, avi, mpg, 3gp, $3 g 2$. 